\title{
The driving factors of real estate stock prices in Indonesia Stock Exchange
}

\author{
Cicih Ratnasih $^{\mathbf{a}^{*}}$ and Zulher
}

${ }^{a}$ University of Borobudur, Jakarta Indonesia

${ }^{b}$ STIE Bangkinang, Kampar Indonesia

\section{H R O N I C L E}

Article history:

Received: February 27, 2021

Received in revised format:

April 292021

Accepted: May 21, 2021

Available online:

May 21, 2021

Keywords:

Price Earnings Ratio

Debt to Equity Ratio

Return on Assets

Real Estate Stock Price

\section{A B S T R A C T}

In this study, the factors to be researched are internal factors related to financial ratios such as market ratios namely Price Earnings Ratio, Leverage Ratio namely Debt to Equity Ratio, and Profitability Ratio namely Return on Assets (ROA) as variables that affect Stock Prices in real estate companies in Indonesia Stock Exchange. The data used are secondary data from time series that have been transformed from the Indonesia stock exchange. The method used is multiple regression with OLS, to find how much the influence of independent variables have as driving forces on stock prices. The results obtained from this study are price earnings ratio, debt to equity ratio, ROA simultaneously affect the stock prices of Real Estate companies in the Indonesian stock exchange. Meanwhile, partially, the three variables deserve to be the driving factor for share prices in real estate companies at the Indonesia Stock Exchange.

2021 by the authors; licensee Growing Science, Canada

\section{Introduction}

According to Law Number 8 Year 1995, the Capital Market is an activity related to public offerings and securities trading, Public Companies related to the Securities it issues, as well as institutions and professions related to securities. The need for information about making investment decisions in the capital market is needed by investors. Conditions like this will directly affect capital market activity, then lead to fluctuations in demand and supply of the number of shares on the stock exchange and ultimately have an impact on stock price changes, so this situation must always be watched out for by special investors for the property and real estate industry. One of the factors that investors can consider in making a decision to invest in a company is the stock price, since the stock price is a reflection of investors' expectations of the factors of earning, cash flow and the level of return required by investors, where these three factors are also very important influenced by macroeconomic performance (Tandelilin, 2010: 133). Stock prices on the stock exchange often change. These stock price fluctuations occur every day, which results in stocks being able to change hands from one investor to another, quickly. Therefore, investors must pay attention to the factors that can affect share prices. These factors are divided into two, namely internal factors and external factors. Internal factors such as company performance are reflected by the company's financial ratios. Meanwhile, external factors such as government policies and fluctuations in the rupiah exchange rate against foreign currencies. According to Tsay and Goo (2006) Debt to equity ratio is a "ratio used to assess debt to equity". This ratio is found by comparing all debt, including current debt, and total equity. This ratio is used to determine the amount of funds provided by the borrower (creditor) and the owner of the company. In other words, this ratio serves to determine every rupiah of own capital that is used as collateral for debt. Mei Yu. (2013) Financial performance refers to a company's ability to generate new resources from day-

* Corresponding author.

E-mail address: cicih ratnasih@,borobudur.ac.id (C. Ratnasih)

(C) 2021 by the authors; licensee Growing Science, Canada doi: $10.5267 /$ j.ac.2021.5.013 
to-day operations over a given timeframe. A company's performance is gauged by its net income and cash from operations. This study uses return on assets (ROA) and return on equities (ROE) to measure profitability.

According to industry solvency ratio standards, a good Debt to equity ratio is above $90 \%$ or 0.90 and the tolerance limit is 2 , where the company is still able to overcome the debt that finances the company's equity. According to Tandelilin (2010: 372), "Return on Assets describes the extent to which the company's assets can generate profits". To calculate ROA we may use the formula for net income after tax divided by total assets. In essence, a descriptive analysis problem can be formulated about the scope of the problem and the analysis of the variables included therein. As for the problem formulation that will be investigated further by the author, namely, how do the Price Earnings Ratio (PER), Debt to Equity (DTE) and ROA influence together or simultaneously affect the share price of real estate companies in Indonesia?

\section{Literature review}

Based on the opinions of experts regarding the meaning of financial management, it can be concluded that financial management is a company activity in the form of planning, budgeting, checking, managing, controlling, seeking, and delivering funds efficiently. These authors document many instances of misclassification; for example, instances where tradable A- shares held by a government agency (Hess et al., 2010). Financial management related to the financial management of companies includes those closely related to corporate financial management, including institutions that are closely related to sources of funding and corporate financial investments and financial instruments. Glick et al. (2005). Findings - The paper finds evidence that large private block holdings are to the benefit of firm value for the full sample. Conversely, for smaller samples of companies without or with very low shareholdings by the various state players, there is some evidence that large private block shareholdings might be to the detriment of firm value (Hess et al., 2010).

Financial accounting standards provide an understanding of financial statements, namely, the Indonesian Accounting Association (2013) explains that "Financial reports are balance sheets and profit calculations in reports of changes in financial position (for example, cash flow reports, or cash flow reports), notes and other reports and materials. an explanation which is an integral part of the financial statements". A financial report is considered as the accounting process and also a summary of the financial transactions which may happen during the relevant financial year. The financial report prepared by the management to respond to the transfer of ownership by the owners of the company.

Meanwhile, the definition of financial statements according to Harahap (2018: 105) "Financial reports describe the financial condition and results of operations of a company at a certain time or a certain period of time". According to Brigham and Houston (2013) "Financial analysis that includes financial ratio analysis, weakness and strength analysis in finance will be very helpful in assessing past management achievements and prospects for the future. This ratio can provide an indication of whether the company has sufficient obligations to meet its financial obligations, the amount of receivables is quite rational, inventory management efficiency, sound investment expenditure planning and a healthy capital structure so that the goal of maximizing shareholder prosperity can be achieved". From this explanation until the author's understanding that the purpose of financial ratio analysis is to help someone better understand a financial report. In Kodithuwakku (2016), the results of the analysis of financial ratios can be used by internal parties as a consideration in future planning, the results of the analysis can also be used by external parties with an interest in the company, such as creditors or suppliers in the context of providing credit or supplying raw materials so that they can show the company's ability to pay its debts in the future. Meanwhile, the capital market according to Gitman et al. (2012) is the meeting place between supply and demand for securities. In this place, market players are individuals or business entities that have been offered by the issuer. Based on the above understanding, it can be concluded that the capital market is a meeting place for parties who have the excess funds with those who need funds by trading long-term financial assets in order to obtain capital.

\section{Methods}

This research is a causal relationship research (Causal Effect), where the research conducted is directed to obtain facts from existing phenomena and seek factual information about the effect of the movement of PER, DER, and ROA on Stock Prices - Real company shares in Indonesia. The type of data used is secondary data, models and analysis techniques using multiple linear regression and residual approaches. For calculation accuracy as well as reducing human error, the Eviews version 9 program is used with the determination of the significance level at the 95 percent confidence level or $\sigma$ (alpha) 0.05 . The population that becomes the object of this research is all financial reports, both quarterly and annual reports of companies that have been audited by public accountants since the company was founded until now. The sampling technique in this study used a purposive sampling method. The purposive sampling method is a method of determining the sample with certain considerations. The sample used is a quarterly financial report that has been audited by a public accountant appointed by the capital market authority for 10 (ten) years, from 2008 to 2018. Thus, the number of samples used is 10 years $\times 4$ Quarterly reports $=40$ samples $/$ Financial Statements. The analytical method used is multiple linear regression models. According to Gordon and Schmid (2000). Multiple linear regression analysis intends to predict how the state (rise and fall) of the dependent variable (criterion), if two or more independent variables as predictor factors are manipulated (increase and decrease in value). So multiple regression analysis will be carried out if the number of independent variables is at least 2 . The equation model of multiple regression is: 
$\mathrm{Y}=\mathrm{f}(X 1, X 2, X 3)$

$\mathrm{Y}=\mathrm{Y}=\mathrm{a}+\beta_{1} \mathrm{X}_{1}+\beta_{2} \mathrm{X}_{2}+\beta_{3} \mathrm{X}_{3}+\varepsilon$

$Y=Y=a+\beta_{1} \ln X_{1}+\beta_{2} \ln X_{2}+\beta_{3} \ln X_{3}+\varepsilon$

Information:
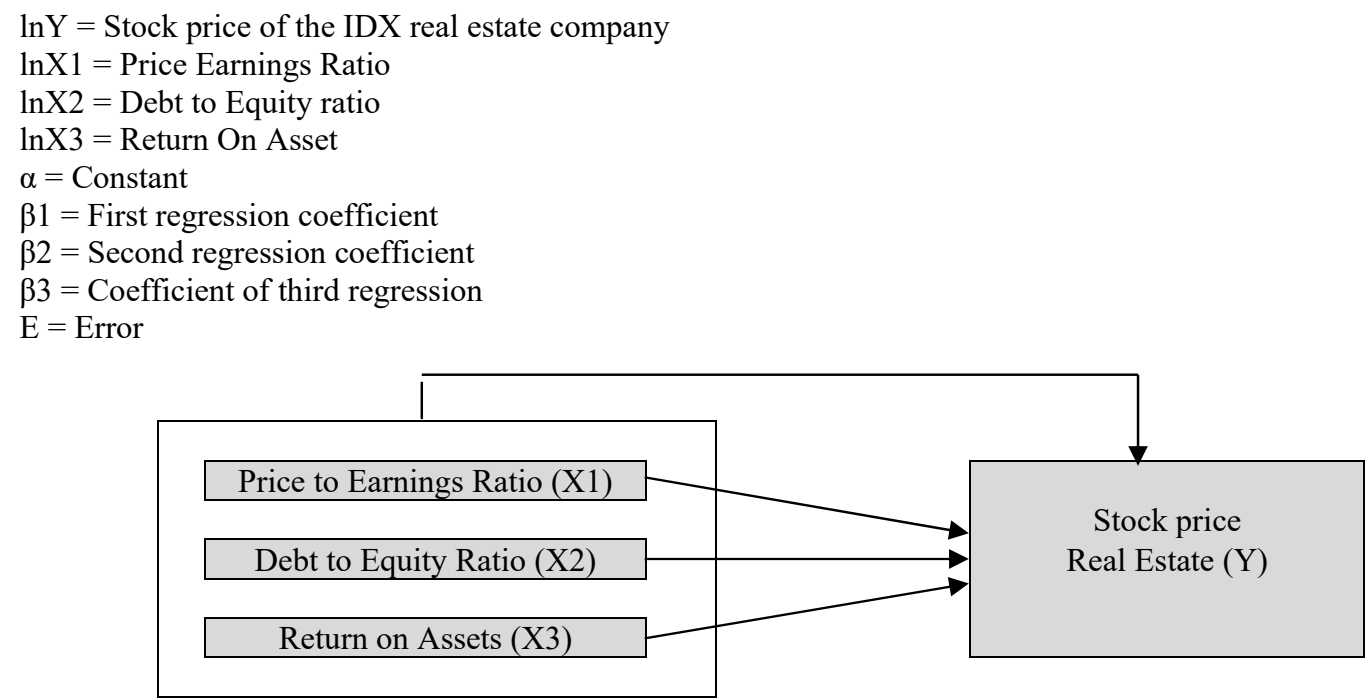

Fig. 1. The proposed study

Source: The data is processed by the author

\section{Results and Discussion}

Following equation results from data processing:

$\mathrm{Y}=\mathrm{f}(\mathrm{X} 1, \mathrm{X} 2, \mathrm{X} 3)$

$\mathrm{Y}=\mathrm{Y}=\mathrm{a}+\beta_{1} \mathrm{X}_{1}+\beta_{2} \mathrm{X}_{2}+\beta_{3} \mathrm{X}_{3}+\varepsilon$

$Y=Y=a+\beta_{1} \ln X_{1}+\beta_{2} \ln X_{2}+\beta_{3} \ln X_{3}+\varepsilon$

$\mathrm{Y}=7.57389+2.828 \ln \mathrm{PER}-4.833 \ln \mathrm{DER}+7.417 \ln R O A+\mathrm{e}$

t-value

(3.067)

$(-1.919)$

Table 1

The summary of the regression analysis

\begin{tabular}{|c|c|c|c|c|}
\hline Variable & Coefficient & Std. Error & $\mathrm{t}$-Statistic & Prob. \\
\hline $\mathrm{C}$ & 7.57389 & 8.228367 & 6.06016 & 0.000 \\
\hline INPER & 2.82804 & 0.921963 & 3.067413 & 0.0048 \\
\hline $\operatorname{lnDER}$ & -4.83357 & 8.226214 & -1.91952 & 0.0800 \\
\hline INROA & 7.417445 & 6.058125 & 2.105123 & 0.0444 \\
\hline R-squared & 0.848152 & Mean dependent var & & 424.3438 \\
\hline Adjusted R-squared & 0.831883 & SD dependent var & & 164.2672 \\
\hline $\mathrm{SE}$ of regression & 67.35304 & Akaike info criterion & & 11.37424 \\
\hline Sum squared resid & 127020.1 & Schwarz criterion & & 11.55746 \\
\hline Log likelihood & -177.9879 & Hannan-Quinn criter. & & 11.43497 \\
\hline F-statistic & 52.13165 & Durbin-Watson stat & & 1.40987 \\
\hline Prob (F-statistic) & 0.000 & & & \\
\hline
\end{tabular}

The F test was conducted by using the level of significance and hypothesis analysis was 5\%. The probability significance value obtained in the table is $0.000000 \leq 0.05$, which means that it has a significant effect. It indicates that PER, DER, and ROA simultaneously have significant effects on stock price of real estate companies listed on IDX in the 2006 - 2018 period. 
The $t$-test was conducted by using the level of significance or $\alpha$ was $5 \%$ or 0.05 . To perform t test is by comparing the probability value of each independent variable against $\alpha$ is $5 \%$.

The effect of PER on Stock Prices of real estate companies in Indonesia, the regression result shows statistically significant on probability value of Price Earnings Ratio is smaller than $\alpha(0.0048 \leq 0.05)$, then It can be concluded that Price Earnings Ratio variable has significant and positive effect on stock prices. Meanwhile, Debt to Equity Ratio shows statistically significant probability value of DER is smaller than $\alpha(0.0000 \leq 0.05)$ and the $t$ statistic is-11.91952, it can be concluded that the variable of DER has significant and negative effect on stock prices. Furthermore, for the effect of ROA on Stock Prices, the results obtained by the regression table show statistically significant probability value of ROA is smaller than $\alpha(0.0444 \leq$ 0.05), it can be concluded that the Return On variable Asset has significant and positive effect on stock prices. This is in accordance with research from Enow and Brijlal (2016).

Testing the coefficient of determination $\mathrm{R}^{2}$ used to measure the ability of the model to explain the relationship between independent variable and dependent variable, the coefficient of determination is between zero and one $\left(0 \leq R^{2} \leq 1\right)$, which is owned by $\mathrm{R}^{2}$ can be fixed with Adjusted $\mathrm{R}^{2}$, The greater the Adjusted value $\mathrm{R}^{2}$ the better the model. From the regression results, the Adjusted $\mathrm{R}^{2}$ value is 0.831883 shows that 83.18 percent shows that the contribution of the influence of PER, DER and ROA to share prices of real estate companies in Indonesia is $83.18 \%$. While the remaining $16.82 \%$ is the influence of other factors outside of this study.

Based on Table 1, the Linear Regression, the Regression Equation is as follows:

$$
\mathrm{Y}=7.57389+2.828040 \text { PER }-4.833557 \text { DER }+7,417445 \text { ROA }
$$

The interpretation of the regression equation is as follows:

1.) Constant Value $=7.57389$ means statistically calculation if all ceteris paribus variables or have a value $=0$, then the share price will increase by 7.57389 units.

2.) PER Coefficient of Regression $=2.828040$, meaning that statistically, the PER increases by 1 unit, assuming other independent variables are considered constant, the share price will increase by 2.828040 units.

3.) DER Coefficient of Regression $=-4.833557$. This means that according to statistical calculations the DER increases by 1 unit, with the assumption that the other independent variables are considered constant, the Share Price will decrease by -574.8335 units.

4.) ROA Regression Coefficient Value $=7,417554$, meaning that statistical calculations ROA increases by 1 unit, with the assumption that the other independent variables are considered constant, the Stock Price will increase by 7,417445 units.

Based on the results of statistical testing / F test shows the factors of influence of PER, DER and ROA simultaneously have a significant effect on Stock Prices, as evidenced by the results of the F / Simultaneous Test statistical test with a probability value of 0.000000 smaller than 0.05 with an Adjusted R-squared result of 83.18 percent, the remaining 16.82 percent is influenced by variables or other factors outside the model under study. While research (Amin \& Hamdan, 2018) One major financial tool was used to measure firm performance, ROA. The study evaluated this relation using several control variables which are: firm size, firm age, financial leverage and industry sector. Based on the results of statistical testing / $t$ test, it shows that the variable Price Earnings Ratio partially has a positive and significant effect on stock prices. The higher the value of the Price Earnings Ratio of a company, the more optimistic the market will look at the future prospects of the economy. And conversely, the lower the Price Earnings Ratio, the more the market will feel anxious and pessimistic about the future of the economy. So, it can be said that investors will be more interested in stocks that have a high Price Earnings Ratio than stocks that have a low PER. A low PER tends to make stock prices fall. PER is the most dominant variable affecting stock prices. The effect is that the greater the earnings given to investors, the higher the share price in the company, Zulher and Ratnasih (2019). The greater the Price Earnings Ratio of a stock, the more expensive the stock will be to net income per share. Stocks that have a smaller Price Earnings Ratio, the better, which means the stock is cheaper. Thus, Price Earnings Ratio has an effect on stock prices. The theory above is in line with the results of research conducted by Delios et al. (2006) which proves that Partially PER has a positive and significant effect on stock prices in pharmaceutical companies on the IDX. Based on the results of statistical testing / $t$ test shows that the variable Debt to Equity Ratio partially has a negative and significant effect on stock prices. Evidenced by the results of the $t$ statistical test / partial test with a probability value of 0.0000 smaller than 0.05 , the coefficient shown in front of the DER variable is negative (-), meaning that the higher the DER value, the Stock Price will decrease. Because the increase in DER indicates that the increase in debt is relatively higher than the increase in own capital. Which is where with the high value of the DER, investors will not glance at the company's shares, with a lack of interest from investors, the share price will decline. Based on the results of statistical testing / $t$ test, it shows that the ROA variable partially has a positive and significant effect on the stock price of real estate companies. Evidenced by the results of the $t$ statistical test / partial test with a probability value of 0.0444 smaller than 0.05 , the coefficient shown in front of the ROA variable is positive $(+)$, the results above are in line with the results of research conducted by Gordon and Schmid (2000), which proves that Partially Return on Assets has a positive and significant effect on share prices in property sub-residence 
sector companies listing on the Indonesia Stock Exchange. A high ROA value indicates that the quality and performance of the company are increasing, so the company's ability to pay dividends increases and the stock price also increases.

\section{Conclusion}

Based on the results of data analysis discussion through proving the hypothesis of the issues raised regarding the factors that affect share prices in real estate companies in Indonesia Stock Exchange, the conclusions can be drawn from this study are as follows:

1) Variables PER, DER and ROA simultaneously have significant effects on stock prices of real estate companies on Indonesia Stock Exchange. Adjusted R-Square value of 83.18 percent, which means the independent variables could describe about $83 \%$ of the dependent variable and the remaining 16.82 percent is explained by other variables outside the research.

2) From the research results it was found that the PER partially has positive and significant effect on stock prices of real estate companies in Indonesia Stock Exchange with probability value of 0.0048 and statistical t-value of 3.067413.

3) From the research results of the study, it was found that DER partially has negative and significant effect on stock prices of real estate companies in Indonesia Stock Exchange with probability value of 0.0000 and statistical t-value of -11.91952.

4) From the research results of the study, it was found that ROA partially has positive and significant effect on stock prices of real estate companies in Indonesia Stock Exchange with probability value of 0.0444 and statistical t-value of 2.105123.

\section{References}

Amin, A. A., \& Hamdan, A. M. (2018). Evaluating the Effect of Ownership Structure on Firm Performance: Evidence from Saudi Arabian Listed Companies. Journal of Economic Cooperation and Development, 39(3), 65-92.

Brigham, E. F., \& Houston, J. F. (2013). Dasar-dasar Manajemen Keuangan, diterjemahkan oleh Ali Akbar Yulianto. Jakarta: PT. Salemba Empat.

Delios, A., Wu, Z.J., \& Zhu, N. (2006). A New Perspectives on ownership indentities in China's listed companies. Management and organization review, 2 (3), 319-343.

Enow, S. T., \& Brijlal, P. (2016). Determinants of share prices: the case of listed firms on Johannesburg Stock Exchange. Journal of Accounting and Management, 6(1), 85-92.

Gitman, L. J., Juchau, R., \& Flanagan, J. (2015). Principles of managerial finance. Pearson Higher Education AU.

Glick, W. H., Washburn, N. T., \& Miller, C. C. (2005, August). The myth of firm performance. In Proceedings of the Annual Meeting of American Academy of Management (pp. 159-171).

Gordon, G., \& Schmid, F.A (2000). Universal Banking and the performance of German Firms. Journal offinancial economic, 58(1-2), 29-80.

Harahap, I. M. (2018). Impact of Bank Performance on Profitability. Scholars Journal of Economics, Business and Management, 5(8), 727-733.

Hess, K., Gunasekarage, A., \& Hovey, M. (2010). State-dominant and non-state-dominant ownership concentration and firm performance: Evidence from China. International Journal of Managerial Finance, 6(4), 264-289.

Kodithuwakku, M. S. (2016). Impact of Firm Specific Factors on the Stock Prices: A Case Study on Listed Manufacturing Companies in Colombo Stock Exchange. International Journal for Research in Business, Management and Accounting, 2(3), 67-76.

Mei Yu., (2013). State ownership and firm performance: Empirical evidence from Chinese listed companies, https://www.sciencedirect.com/science/journal/17553091/ China Journal of Accounting Researchjournal homepage: www.elsevier.com/locate/cjar6/2.

Tandelilin, E. (2010). Portofolio dan Investasi: Teori dan aplikasi. Kanisius.

Tsay, T. Y., \& Goo, Y. J. (2006). The Relationship of Profitability and Growth with Stock Market Returns in the Electronics Industry. International Journal of Management, 23(4), 763.

Zulher, Z. Ratnasih, C. (2019). Determinants of manufacturing company stock prices. International Journal of Education Review, 6(2), 54-62. 
(C) 2021 by the authors; licensee Growing Science, Canada. This is an open access article distributed under the terms and conditions of the Creative Commons Attribution (CC-BY) license (http://creativecommons.org/licenses/by/4.0/). 